\title{
The Influence of the "Face" tradition on the Chinese Education system
}

\author{
Tatyana Prutskikh ${ }^{1, *}$, Elizaveta Merkulova ${ }^{2}$ \\ ${ }^{1} \mathrm{PhD}$ in Philology, Department of Oriental Languages, Faculty of Humanities, St. Petersburg State University of Economics, Russia \\ ${ }^{2}$ Student, Linguistics, Faculty of Humanities, St. Petersburg University of Economics, Russia
}

\begin{abstract}
The paper covers linguistic and cultural aspects of the concept of "face" and established combinations with the synonyms 面 and 脸. It compares some of the distinctive characteristics of the Chinese education system throughout history and assesses the influence of the "face saving" tradition on the Chinese education system. The paper studies linguistic and cultural aspects of the concept of "face", which refers to cultural understanding of respect, honour and social standing. The authors established combinations with the synonyms 面 and 脸, such as, “having face” (有面子), “not having face” (没面子), “losing face” (丢 脸/丢面子), “giving face” (给面子/给脸) etc. The essay compares some of the distinctive characteristics of the Chinese education system throughout history and assesses positive and negative influence of the "face saving" tradition on the Chinese education system.
\end{abstract}

\section{Cultural aspect of the concept of "face"}

The norm of regulated social behavior has always been and still today is a solid foundation of Chinese culture. Although the speed of trade and economic growth as well as scientific and technological progress has been gaining momentum over the last few decades, Chinese mentality has changed much less. We aim to explore the evolution of Chinese society through the example of the "face saving" tradition.

According to E. Hall's model, China is a highly contextual culture [1]. China is a country with a marked network of social interactions. Information is not only conveyed by speech, but also by a person itself, as well as conditions in which the communication takes place. Every detail turns out to be important: how a person looks at something, how long a pause is held between sentences, how he or she stands, the posture of hands, under which conditions, in which place and at which time the communication happens. This type of culture is also determined by rich experience, centuries-old traditions and rules tested throughout the ages, most of which are still relevant today. A highly contextual culture is homogeneous, stable and coherent; it has multiple hidden norms and rules of behavior, most likely, are almost incomprehensible to other cultures.

Chinese society has almost always functioned on the basis of personal relationships. To allow for a good standard of living, the Chinese had to create their own network of personal connections. Much in the life of a Chinese, including the individual's well-being, depended first and foremost on the presence of "social trust". Anything that could lead to "loss of face" negatively affected "social trust". The responsibility of people for each other and for themselves was extremely high - "Do not do to others what you do not wish for yourself, and then there will be no offended ones either in the State or in a family" [2]. This is exactly how, according to Confucianism, people should be treated.

Shaming is an important instrument when raising children in China. The use of such methods forms an emotional complex of relationships associated with the concept of "face". In this social system, close attention is paid to the "person"; that affects you yourself as well as all those around you, even those with only a minor relation to you. Relatives, friends, colleagues should strive for loyalty in order to fulfill obligations towards each other. A disloyal individual loses "face" [3].

"Caring for another person's "face" is something more than just a simple social norm, according to which everyone tries not to influence the "face" of the other, and as a result, everyone's "face" is saved. Not caring about someone else's "face" even means causing harm to your own "face" to some extent" [4].

The modern Chinese State, whilst preserving the ancient Confucian values such as 礼 lǐ "etiquette, ritual, decency", takes care of the young generation mastering these rules of etiquette. Under rapidly evolving situations in the international arena, it is essential to study not just domestic etiquette, but also the etiquette of foreign countries. Etiquette lessons are already included in the school curriculum, and "various schools of etiquette and good manners have been opened for adults. Popular publications about the rules of decent behavior are published, and special training programs are held". Based on empirical studies of the priority of etiquette different functions in the minds of Chinese students, the

Corresponding author: pruta@mail.ru 
authors conclude that there are traditional moral principles in the minds of modern Chinese youth, namely, the desire to ensure "face saving" for all participants of communication [5].

\section{Linguistic aspect of the concept of "face"}

In modern Chinese, there are two main hieroglyphs for "face": "mian" (面 miàn), or "mianzi" (面子 miànzi) - a face as social reputation, prestige, good name, dignity and honor, and "lian" (脸 liăn) - face as a part of the body, front part, appearance. Over time, the distinction between "mian" and "lian" has been somewhat erased, and both words now have the same connotation. The dictionary provides the following.

脸古汉语字典解释 脸 Explanation from Old Chinese Dictionary [7]:

1) <名>面项的上部 upper cheeks;

2) <名>指整个面部 indicates the entire face;

3) <名>面子; 颜面 face, appearance, appearance; conscience, reputation.

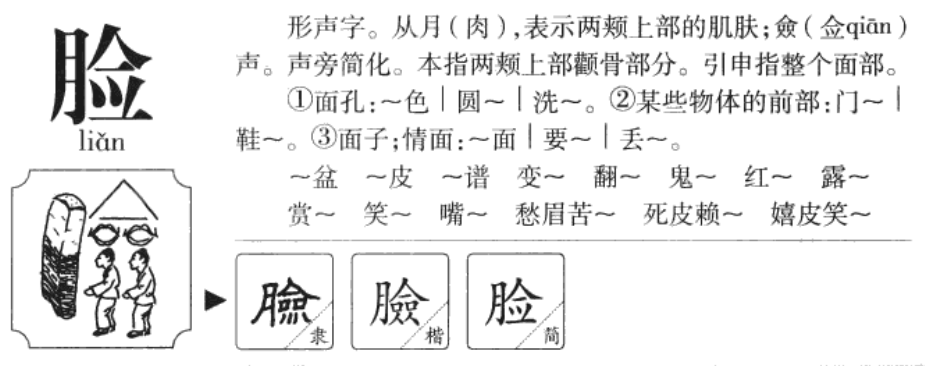

脸 lian is a hieroglyph of the phonetic category. It consists of the key "meat", denotes the muscles and skin on the upper part of cheeks; consonant with the hieroglyph 佥 qian ("universal, joint"). Simplified initial. The basic meaning is the part of the frontal bone located above two cheeks. Figurative (broader meaning) is the whole face.

1) Face, physiognomy: facial expression, round face, to wash.

2) The front of an object: front, top (shoes).

3) Person, reputation; dignity: face, strive to save face, lose face.

Wash basin, washbasin sink; skin on the face; mask; bian lian (Chinese opera art); back side; demon mask; red, bashful face; show your face, appear in your eyes; to praise; smile; face, appearance; frown eyebrows and haggard face; shameless; hippie emoticon [6].

面古汉语字典解释面 Explanation from Old Chinese Dictionary [7]:

1) <名>脸 face;

2) 〈动〉面向 ; 面对着 turn to face ..., stand in front of your face;

3）<副> 当面 in person, in person, eye to eye;
4) <名>方位 ; 方面 side, location, direction, aspect;

5) <名>平面 ; 表面 flatness, surface, outer side; <量> acc. word meaning "side".

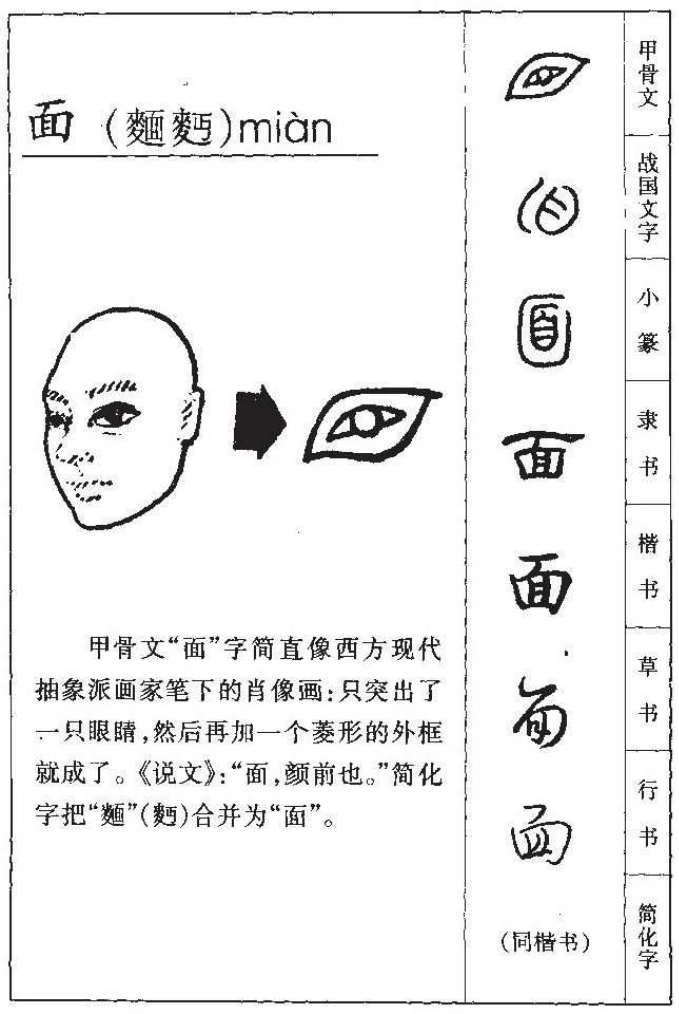

The 面 miàn hieroglyph in the oracle bones (Jiaguwen) is just like a portrait painted by a contemporary Western abstract artist: only the eye is highlighted, then a diamond-shaped frame is added. Shuowen: "face, facial expression". The traditional hieroglyph "麺" has changed to the simplified "面" [6].

Even though the hieroglyphs 面 and 脸 are synonymous, they can describe quite different figurative characteristics. We propose to consider some wellestablished combinations with the studied hieroglyphs.

Table 1. Well-established combinations with hieroglyphs 面 and 脸.

\begin{tabular}{|l|l|}
\hline \multicolumn{3}{|c|}{ Equivalent use of hieroglyphs } \\
\hline $\begin{array}{l}\text { 丢脸 diū liăn to lose face, } \\
\text { disgrace; dishonor, bring } \\
\text { dishonor, embarrass }\end{array}$ & $\begin{array}{l}\text { 丢面子 diū miànzi to lose } \\
\text { face, disgrace }\end{array}$ \\
\hline $\begin{array}{l}\text { 红 脸 hóngliăn red } \\
\text { (embarrassed) face; confused } \\
\text { (ashamed) look }\end{array}$ & $\begin{array}{l}\text { 愧无 面 目 见iànmù 人iàn rén not to know wú } \\
\text { where to hide from shame, be } \\
\text { afraid to look people in the } \\
\text { face out of shame }\end{array}$ \\
\hline $\begin{array}{l}\text { 给脸 gěiliăn to uphold (smb.) } \\
\text { prestige }\end{array}$ & $\begin{array}{l}\text { 给面子 gěi miànzi to respect } \\
\text { feelings (of someone), to } \\
\text { show (do) honor (to smb.); } \\
\text { respect; out of respect for } \\
\text { (smb.) dignity }\end{array}$ \\
\hline \multicolumn{2}{|c|}{ Differences in the use of hieroglyphs } \\
\hline 翻脸不认人 fānliăn bùrènrén & 外面 wàimiàn appearance; \\
\hline
\end{tabular}




\begin{tabular}{|c|c|}
\hline $\begin{array}{l}\text { to change attitudes and stop } \\
\text { recognizing; to quarrel and } \\
\text { stop saying hello; to quarrel } \\
\text { and start turning up your } \\
\text { nose; do not communicate } \\
\text { anymore }\end{array}$ & outer side; exterior \\
\hline $\begin{array}{l}\text { 不要脸的人 bùyào liăn de } \\
\text { rén shameless }\end{array}$ & 无面目 wú mi \\
\hline $\begin{array}{l}\text { 脸皮厚 liănpíhòu shameless, } \\
\text { arrogant, impudent; thick- } \\
\text { skinned; unbreakable }\end{array}$ & $\begin{array}{l}\text { 留面子 liú miànzi to keep } \\
\text { face, stay with the same } \\
\text { reputation }\end{array}$ \\
\hline $\begin{array}{l}\text { 长脸 zhăng liăn to give, add } \\
\text { significance }\end{array}$ & $\begin{array}{l}\text { 侵面 qīn miàn "Invade the } \\
\text { face", spoil the reputation }\end{array}$ \\
\hline
\end{tabular}

The cultural and psychological phenomenon of "face" plays an essential role in Chinese social etiquette. "Face" is society's evaluation of how a person complies with social norms. This is social status, the ability to comply not only with norms of internal control but also with external norms of society itself. The loss of "face" threatens the Chinese to lose social status, connections, support, and sense of safety. To have or maintain "face" was traditionally considered even more important than to have professional skills [8].

\section{The influence of the "face saving" tradition on the Chinese education system}

The face-saving tradition affects all spheres of life in China, and education is no exception. Chinese attitude towards education has changed over the decades since it became available to and mandatory for all. The Chinese education system is considered one of the best in the world, as China trains outstanding specialists in all fields, especially in practical, exact sciences. Each year, more and more people study Chinese and prepare to get an academic degree in China. For a long time, China has been considered not only as an ancient Eastern civilization, but as a powerful industrial nation which follows the path of development, modernization, scientific progress and cooperation.

The development of any society is based on its education system; therefore, despite the difference in the duration of the periods under consideration, it seems appropriate to take a brief view at Chinese education up to the middle of the 20th century, and from the middle of the 20th century until today.

Table 2. Comparison of Chinese education system in different historical periods.

\begin{tabular}{|l|l|}
\hline $\begin{array}{c}\text { Until the middle of the 20th } \\
\text { century }\end{array}$ & $\begin{array}{c}\text { From the middle of the 20th } \\
\text { century until today }\end{array}$ \\
\hline $\begin{array}{l}\text { Education was considered } \\
\text { prestigious and was available } \\
\text { only for privileged or wealthy } \\
\text { families. It was closely } \\
\text { connected with a person's } \\
\text { status, derived from their } \\
\text { status or wealth. }\end{array}$ & $\begin{array}{l}\text { Education is accessible to all, } \\
\text { the main goal of the State is } \\
\text { to all (free compulsory 9-year } \\
\text { system education since 1986). }\end{array}$ \\
\hline $\begin{array}{l}\text { Women could not get an } \\
\text { education unless they were }\end{array}$ & $\begin{array}{l}\text { Anyone at any age can get } \\
\text { education (there are special }\end{array}$ \\
\hline
\end{tabular}

\begin{tabular}{|c|c|}
\hline $\begin{array}{l}\text { a wealthy family } \\
\text { /omen's education } \\
\text { fferent from men's). }\end{array}$ & ults in the country). \\
\hline $\begin{array}{l}\text { Ane objective of education in } \\
\text { Ancient China was to groom a } \\
\text { erson who was well-read, } \\
\text { olite, able to behave in } \\
\text { ociety, in harmony with his } \\
\text { oul [9]. }\end{array}$ & he best \\
\hline $\begin{array}{l}\text { Children of wealthy families } \\
\text { learned to read, write, count, } \\
\text { sing, read poems, play } \\
\text { musical instruments. Natural } \\
\text { and exact sciences were } \\
\text { ignored. } \\
\text { knowledge was poor and } \\
\text { formal [10]. }\end{array}$ & $\begin{array}{l}\text { First, students are taught the } \\
\text { basics in respective subjects } \\
\text { to expand their horizons and } \\
\text { to lay the foundation for a } \\
\text { more in-depth education and } \\
\text { specialization later on. The } \\
\text { program includes compulsory } \\
\text { disciplines: mathematics, } \\
\text { physics, chemistry, biology, } \\
\text { geography, foreign } \\
\text { languages. }\end{array}$ \\
\hline $\begin{array}{l}\text { Children were not told } \\
\text { anything about other } \\
\text { countries, they were taught } \\
\text { the idea that "China is the } \\
\text { whole world" [10], "middle } \\
\text { state". }\end{array}$ & $\begin{array}{l}\text { Chinese people learn foreign } \\
\text { languages to study abroad in } \\
\text { order to establish strong } \\
\text { relationships with other } \\
\text { countries. China is not the } \\
\text { whole world, but one of the } \\
\text { most powerful nations; } \\
\text { development and cooperation } \\
\text { are critical to sustain its } \\
\text { status. }\end{array}$ \\
\hline $\begin{array}{l}\text { The primary task was to } \\
\text { master writing, hieroglyphics. } \\
\text { People who could write were } \\
\text { highly valued, there were only } \\
\text { few of them, they were even } \\
\text { referred to as "priests". } \\
\text { Calligraphy skills were } \\
\text { passed from one generation to } \\
\text { another, along with writing } \\
\text { tools. }\end{array}$ & $\begin{array}{l}\text { to } \\
\text { y is } \\
\text { ect. } \\
\text { phs }\end{array}$ \\
\hline \multicolumn{2}{|c|}{$\begin{array}{l}\text { "Cramming" is the main way of studying, students have to } \\
\text { memorize a lot. When answering a question in class, a student } \\
\text { turns away from the text and tries to reproduce it from memory } \\
\text { - the Chinese hieroglyph 背 bèi means "to turn his back" and } \\
\text { "to learn by heart". }\end{array}$} \\
\hline \multicolumn{2}{|c|}{$\begin{array}{l}\text { A teacher is a person of the highest esteem, ranked as high as } \\
\text { the State and-parents. } \\
\text { In the old days, the teacher would be the spiritual mentor of a } \\
\text { student throughout his studies. In honor of the teacher, students } \\
\text { would light candles and bow low three times to show their } \\
\text { respect and their willingness for unquestioning obedience. } \\
\text { In modern society, the respect and prestige of the laoshi } \\
\text { profession (老师 lăoshī "teacher") is preserved. }\end{array}$} \\
\hline
\end{tabular}

High-quality education always remains prestigious, it guarantees a successful working career, prosperity and well-being, therefore, regardless of the family's income, Chinese parents invest strongly in a child's education, because he or she is a new "face" of the family, he or she should be the best. From an early age, Chinese children learn the principle of "face saving", as they do not just represent themselves and their own face, but also the "face" of the entire family; to disgrace themselves would mean to disgrace the family. From an early age, children learn that it will be difficult for them to get ahead in life, 
that they constantly need to "fight for a place in the sun", delivering the best results and keeping up with others.

Any phenomenon should be investigated comprehensively, that is why we tried to highlight key positive and negative aspects of the impact of the "keeping face" tradition on the Chinese education system.

Table 3. The impact of the "saving face" tradition on the Chinese education system.

\begin{tabular}{|l|l|}
\hline \multicolumn{1}{|c|}{ Positive impact } & \multicolumn{1}{c|}{ Negative impact } \\
\hline $\begin{array}{l}\text { An open-minded multiple } \\
\text { personality }\end{array}$ & Identity issues, all the same \\
\hline $\begin{array}{l}\text { Sense of community spirit, } \\
\text { patriotism }\end{array}$ & $\begin{array}{l}\text { Denunciation system, } \\
\text { constant spying on each other }\end{array}$ \\
\hline $\begin{array}{l}\text { Pupils perform well so that } \\
\text { they can and will become } \\
\text { highly qualified specialists }\end{array}$ & $\begin{array}{l}\text { A lot of attention is paid to } \\
\text { cramming, while own } \\
\text { opinions and reflection are } \\
\text { unimportant }\end{array}$ \\
\hline $\begin{array}{l}\text { Decency, discipline, } \\
\text { subordination }\end{array}$ & $\begin{array}{l}\text { Lack of personal life, } \\
\text { delaying marriage, childfree } \\
\text { issues }\end{array}$ \\
\hline $\begin{array}{l}\text { Self-control, emotional } \\
\text { modesty }\end{array}$ & $\begin{array}{l}\text { Overstress, exhaustion, } \\
\text { mental illnesses }\end{array}$ \\
\hline $\begin{array}{l}\text { Respect for elders, obedience } \\
\text { to tradition }\end{array}$ & $\begin{array}{l}\text { Education "for parents", not } \\
\text { because of one's aspiration, } \\
\text { but "to make the parents } \\
\text { proud of their child" }\end{array}$ \\
\hline
\end{tabular}

\section{Conclusion}

Competition, stress, thinking about others' opinions, benefit-seeking, growing intensity of life, epidemics these are components of progress and life in a rapidly changing civilization. All of us, regardless of our cultural heritage, are modern people, wearing public "faces" masks to adapt, to protect ourselves and to achieve success.

China has always stayed faithful to its traditions, has shown respect for its past. It has been cautious but also deliberate when adopting new ways, so changes in the life and the mentality of the Chinese happen gradually the search for a reasonable compromise between "saving face" associated with excessive efforts in pursuit of leadership and the opportunity to do what you love, showing one's individuality and creativity. China has always believed that it is necessary to develop and progress by relying on its inner strength, but at the same time acknowledged that it is impossible to shield itself from the outside world.

China has always stayed faithful to its traditions shown respect for its past, it has been cautious but also deliberate when adopting new ways. Thus, changes in the life and mentality of the Chinese happen gradually. They search for a reasonable compromise between "saving face" which takes excessive efforts in pursuit of leadership and the opportunity to do what you love, showing one's individuality and creativity. China has always believed that it is necessary to develop and progress by relying on its inner strength, but at the same time acknowledged that it is impossible to shield itself from the outside world.
Having made a historic transition from isolation to all-vector openness, China generously shares its experience, knowledge and achievements, and now sincerely hopes to fulfill the goal of shared respect, prosperity and fruitful cooperation between different countries of the world [11].

The tradition of "saving face" and everything related to a person's social status in China has many nuances. This topic is intertwined with famous Chinese "connections" (or 关系 guānxì); there are personal, business and economic connections, which are established and formed only through "face". The framework of "face" could, of course, be taken further than education. It could be assessed in areas such as the specifics of doing business in China, business etiquette, gifting, tourist travel, etc. - all of which open up for further perspectives and research into the concept of "face".

\section{References}

1. E.T. Hall, Beyond Culture (1976) URL: https://monoskop.org/images/6/60/Hall_Edward_T_ Beyond_Culture.pdf

2. A.S. Martynov, Confucianism. Lun Yu., St. Petersburg.: "Petersburg Oriental Studies", 2, 209370 (2001)

3. "Face" as a basic concept of the concept of the Chinese language URL: https://www.synologia.ru/a/\%C2\%AB\%D0\%9B\%D 0\%B8\%D1\%86\%D0\%BE\%C2\%BB_\%D0\%BA\%D 0\%B0\%D0\%BA_\%D0\%B1\%D0\%B0\%D0\%B7\%D 0\%BE\%D0\%B2\%D1\%8B\%D0\%B9_\%D0\%BA\%D 0\%BE\%D0\%BD\%D1\%86\%D0\%B5\%D0\%BF\%D1 $\% 82$

4. K.I. Tertitsky, The Chinese: Traditional Values in the Modern World, M. 347 (1994)

5. O.I. Danilenko, T. Lee, Assessment of the importance of etiquette functions by Chinese students (Bulletin of St. Petersburg University, 16, 67-78 2016)

6. 字源查询 Search for the origin of the word URL: http://qiyuan.chaziwang.com/etymology-7477.html

7. 词典网 Network of Dictionaries URL: https://www.cidianwang.com/guhanyu/lian2877.htm

8. A.A. Maslov, Observing the Chinese. Hidden rules of conduct, M.: Ripol-classic, 288 (2010) URL: http://www.cn888ru.com/media/maslov_a_a_nablyu daya_za_kitaicami_skrytye_pravila_povedeniy.pdf

9. Education in Ancient China (2021) URL: https://spravochnick.ru/pedagogika/obuchenie_v_dr evnem_kitae/

10. D.V. Kalyuzhny, Another history of science. From Aristotle to Newton, M. 950 (2002)

11. China's peaceful development (2021) URL: http://by.chinaembassy.org/rus/zt/zfbps/t868717.htm 